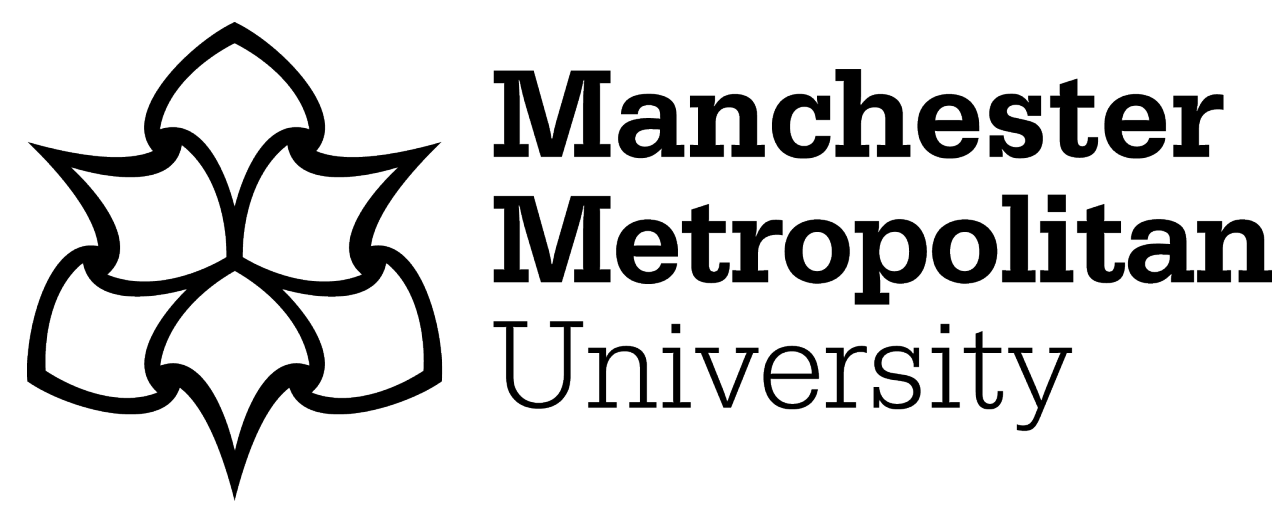

Hidalgo-Bastida, Lilia and Tanskanen, Ilona (2018) Autobiographical digital stories as means to documentation and reflection for biomedical students. In: 10th International Conference on Education and New Learning Technologies, 02 July 2018 - 04 July 2018, Palma de Mallorca (Spain).

Downloaded from: https://e-space.mmu.ac.uk/621785/

Version: Accepted Version

DOI: https://doi.org/10.21125/edulearn.2018.2751

Please cite the published version 


\title{
AUTOBIOGRAPHICAL DIGITAL STORIES AS MEANS OF DOCUMENTATION AND REFLECTION FOR BIOMEDICAL STUDENTS
}

\author{
Ilona Tanskanen ${ }^{1}$, Araida Hidalgo-Bastida ${ }^{2}$ \\ ${ }^{1}$ Arts Academy, Turku University of Applied Sciences, FINLAND \\ ${ }^{2}$ School of Healthcare Science, Manchester Metropolitan University, England, UNITED \\ KINGDOM
}

\begin{abstract}
This work reflects the collaboration between Biomedical Scientists at Manchester Metropolitan University (UK) and Artists at Turku University of Applied Sciences (Finland) to use autobiographical digital stories as means of reflection for students in their last year of the integrated Masters in Biomedical Science (MBioMedSci) at Manchester Metropolitan University, Manchester, England.

Students were invited to participate voluntarily in a pilot workshop as an additional activity to support their professional development. This workshop aimed to tell their professional life story (digital story) and to associate it with their wider autobiography, to help students reflect on their student experience and clarify which path they wanted to follow after graduation. Also, importantly, the workshop was not based only on their scientific work.

Students completed the workshop activities, as well as questionnaires prior and post workshop, on personal experiences and skills. Results demonstrated that the workshop helped students to increase their self-awareness, as well as to identify and clarify their career pathways.

From the individual's point of view, it was important to realise the choices they made and the options future brings. This art-based method empowered students and will be applied in future collaboration in joint biomedical studies.
\end{abstract}

Keywords: Self-reflection, biomedical science, auto-biographical process, digital storytelling, artbased methods, empowerment, creative writing

\section{INTRODUCTION}

Undergraduate courses on biomedical sciences are often restricted in their curricula by a programme agreed between universities and the relevant professional bodies. Accreditation from such bodies focuses on guaranteeing the highest standards of training, education and assessments for biomedical scientists. Even though professional accreditation in incorporating in their new requirements professionalism and employability skills, biomedical science courses are still heavily focused on the scientific aspect, not offering enough training on soft skills, such as digital tools and reflective writing, which are key for a holistic approach on the biomedical scientist training. These tools, if used timely, can help individuals to identify professional development opportunities, as well as, improving performance at their workplace. As such, we consider that these tools are key for biomedical but also other students, to express and understand their journey at university when becoming biomedical professionals, as well as to reflect on what they aspire for their career, while providing new digital skills.

At Turku University of Applied Sciences (TUAS) Arts Academy, autobiographical process has been part of master students' curriculum as competence to lead oneself is needed especially, but not only, in the arts sector careers. Art work is often composed of different kinds of tasks, and it includes identity work, as well as excellent communication skills, including use of multimedia resources. These are only some of the reasons why skills of self-reflection and storytelling are needed [1] [2]. Master students at TUAS Arts Academy write diaries, tell their professional autobiographical digital stories and have used digital storytelling also as a mean of presenting information in thesis], such as artists Petra Kallio [3] and Katja Juhola, who presents her digital professional life story on her website [4]. 
In the autobiographical process in higher education studies, a career path of professional identity is formed, during which the personal interests, skills, competence and learning, as well as needs of development, are highlighted. The question of "who and what kind of expert I am in my field" seeks to be answered. The result may be a professional autobiography - or even several. Professional identity is built up in sight piecewise. Professional growth is part of personal growth, constructing and reforming professional identity and it's change [5].

The autobiographical process and storytelling have been used and studied as tools to research and develop action and cognitive processes especially in the social and educational studies [5]. In an autobiographical work, the author gives form and meanings to one's own thoughts, experiences and observations [6].

The basis for autobiographical work is creative writing, freewriting. Such a writing style has been found to play an essential role in promoting creative work, especially for authors, but also in other creative activity [cf. 7]. Autobiographical writing and stories lead to a journey of exploration into the memory. The target may be an entire life story or the text can be more focused.

In an autobiographical process four aspects are combined: the author, the object, the spectator and the actor - all these roles are carried out by the same person. This is one of reasons why autobiographical work is captivating and gives the opportunity to reflect oneself. The author is telling his or her own life story, (s)he is the actor, who is living the life, and also makes observations about the object, me. [cf. 8]

Autobiographical texts can serve as a means of reflection or (artistic) expression. Biographical writing has often therapeutic effects, and it is used a therapy tool. However, biographical writing has its own space, alongside the therapeutic and fiction writing. Because of this, autobiographical texts can be done either to be private, or for distribution in the public domain

Another methodological basis in this work is storytelling. For example, Alan Lambert and Dana Atchley has been developing it for decades [cf. 9]. In digital storytelling verbal expression in used in voiceover stories alongside photographs, music, effects and written texts.

By telling the story we can bring out something that has not previously been noticed for one reason or another. Telling the story in a group produces an experience of being seen and heard, which is important for expression and identity. Discovering new ways of expression widens the capacity of thinking, reflection, interpretation and acceptance of others. Storytelling highlights the individual but also cultural structures of narratives. The idea of who I am is based on the process where the author is examining his/her actions, feelings and thoughts as an another being and is telling stories about them to others - and listening others' stories too [8] [9] [10].

\section{METHODOLOGY}

In the pilot workshop at Manchester Metropolitan University (MMU), biomedical master students were asked to prepare prior to the workshop by completing a pre-workshop activity. This consisted on students gathering 20 digital photographs that had something to do with how (s)he became biomedical student, and one printed picture of the most meaningful photograph for this. Before the workshop started activities, students were asked to answer questionnaire 1, questions concerning awareness, previous experiences and expectations for the autobiographical digital stories' workshop. The venue provided the equipment needed for the workshop, PC and headset, for each participant, as well as access to internet.

The workshop was planned to be conducted over three days to allow enough time of reflection. The stages included the following activities: A) ice breaking: everyone presented the meaningful picture and told why this picture is special at the moment, B) introduction to workshop: continuum of work shop, C) raw stories: writing stories using structured freewriting method, D) writing stories for voice over using raw stories and shared experiences in writing, E) voice over recordings, F) photos, voice over etc. media loading on Wevideo, G) editing videos, H) presenting videos: sharing and reflecting and I) feedback.

In structured freewriting students wrote texts for themselves only. These texts, the raw stories, were written to be used in voice over stories to the digital stories though. The instructor (Ilona Tanskanen) gave the words to begin each five minutes' writing session. [cf. 11] With the beginning words students were guided to focus on, 1) the way to MMU master biomedical student (dreams, obstacles, turning points, helpers etc.), 2) education as experience (social life, skills, knowledge, interests etc.), 3) 
professional identity (interests, strengths, developing plans, opportunities etc.), 4) future work (the vision of year 2023, workplace, tasks, responsibilities etc.).

The process of raw stories proceeded from freewriting session to reading one's own raw texts and underlining the most meaningful words and expressions. Students were asked to look for metaphors or symbols from their raw texts.

The students also shared with each other such parts of their raw texts they wanted to share. The raw stories were not shown or read aloud - only parts of them were shared. The students got peer feedback in which was pointed out things and expressions that were found out most interesting.

The voice over stories were written after that. The raw texts were used as much the author wanted to use his/her own raw material. Digital stories were to be 2-3 minutes long, and the voice over stories for them could be max. 300 words. Completed voice over stories were read aloud and recorded.

Although the students were advised to bring photographs for the workshop, they only brought one, the most important in their lives; hence, they had to use free images (Creative Commons) from Pexels (www.pexels.com) and Pixabay (www.pixabay.com) to complete the digital work. When their own album photographs are used in the digital stories, the result is very personal and usually brings out emotions and happenings, that are at the same time very individual and common and connect people. But own photographs are not necessary in making digital stories, because many free images are available.

The digital stories were edited in Wevideo online video editor. Wevideo was chosen, because it is free, available via internet, has good editing options and is easy to use. Students received a brief introduction to the video editing and started to edit their digital stories straight after voice over recordings although this was meant to happen next day. They got in to Wevideo very fluently and wanted to continue editing in the evening at home.

By the second day, students had their digital stories almost ready to be finished and published. After some minor editing, we were able to have premiere and feedback. Three days' workshop turned to two days' - because the participants were so keen on completing their digital stories, and skilful with using Wevideo - although they had no previous experience of it.

At the end of the workshop, experiences were discussed and students filled the questionnaire 2, in which they were asked about their awareness and experiences in the workshop. The discussion also included picture cards to help to tell about one's feelings and thoughts - as they were used also in the beginning of the workshop. The students were asked to choose the pictures matching their ideas and then show the images and tell about things that they found out interesting in them.

The aim was not to create an entire life story or an autobiography, merely a kind of story the author wanted to tell concerning his or her study path - which had some connection to author's experiences, feelings and thoughts. Telling a full autobiography is one tradition of autobiographical writing, but not the only one. [cf. 6] The question is about making visible, sharing and reflecting the content of one's own mind. Telling about one's own experiences is identity work, forming a story about who I am [cf. 5].

\section{RESULTS}

This project evaluated students' perceptions on their student journey, future career and selfawareness, prior and post-workshop, using a questionnaire designed by the team before the workshop started and at the end of the workshop. The results demonstrated that the workshop added a little students' self-awareness and produced feeling of competency in digital skills.

\subsubsection{Questionnaire (1) before the start of workshop - Previous knowledge}

Before the workshop started students were asked to answer questions concerning awareness, previous experiences and expectations for the autobiographical digital stories' workshop. In their answers, it turned out that they felt themselves to be very aware about the reasons or the life events that made them choose the biomedical master studies, the most important experiences in the university as well as the future plans, desires and dreams. They had no previous experience of writing diary or other kind of biographical texts or video making. The students expected to gain different view on how to present information, experience in free writing and in storytelling, learn about editing 
photographs and compiling them into video, learn what an autobiographical digital story is and how to make it.

\subsubsection{Questionnaire (2) after the workshop - Experiences and impacts}

In the end of workshop students filled questionnaire 2, in which they were asked partly the same questions about awareness as in the questionnaire 1 before the workshop started. Instead of expectations they were now asked about their experiences. Since the students felt themselves to be well aware about the life events and their path to Manchester Metropolitan University, it was not seen big changes in answers compared before or after the workshop. Some growth though happened in awareness about the future desires and dreams.

According the questionnaire answers the workshop met students' expectations excellently, and they felt that they would like to make some other kind of digital stories in the future. However, freewriting was mentioned in one answer as difficult or unpleasant; session took little more than one hour, and students were to write that long without break. Nothing else was mentioned as unpleasant or difficult thing.

The workshop seemed to have had empowering impact since being able to produce a short film and being able to break down meanings of stories were mentioned as most significant, interesting or rewarding in the workshop. The workshop experience was mentioned as eye opening and different compared to normal activities.

Also in the digital stories students made in the workshop there are some elements that point to the empowering impact. In one of them the narrator encourages the mistreated "prove them wrong". In another digital story narrator seems to have understanding and approving attitude towards life, growth and changes as fundamental property of it.

\subsubsection{Piloting workshop - Common Understanding for Future Collaboration}

This workshop experience hands on was important for the future collaboration. It raised the awareness of this kind of art based method and its impacts. Autobiographical methods will be applied in future collaboration also for example in laboratory diaries in joint courses.

\section{CONCLUSIONS}

The pilot work proved to be a fruitful and inspiring experience for all participants, including the leading academics (Araida Hidalgo-Bastida (MMU), Marko Björn (TUAS) and llona Tanskanen (TUAS)). Multidisciplinary and international collaboration is needed in pedagogical research and development for many reasons, one of them is the essence of self-reflection, which is helped by interaction between different kinds of mind-sets. Self-reflection skills are needed at workplaces in research and development but also leading one's operations. The other reason is need of multimedia skills in online teaching. More and more students as well as teachers need skills to communicate virtually. But not only students and teachers - online communication is part of the workplace interaction too.

For the student, the self-reflective process is a platform to study one's own development, actions, notions and feelings - professional identity as entity. For educational research and development, the students' narratives offer data, which can give useful information to be taken into account in learning design. They can be directed to reflect and form students' knowledge, skills and character - which are the elements of proficiency in today's but also futures work life.

Collaboration should now proceed to the continuum of self-reflective process in master studies. What kind of targets there would be in different stages of training? What kind of methods could be applied in pedagogical solutions? In applying the autobiographical art based methods, the questions to be answered in future are: how to organize autobiographical digital storytelling workshops online and for big student groups, and how to secure the impact of group process and dialogue - which have been found out very often the most meaningful things in art based methods, which usually have been used in rather small workshops [12] [13] [14].

This work is evolving into a collaboration for research and development in applying autobiographical methods in biomedical studies at MMU and TUAS but maybe also with other partners, representing 
working life as well. The very next steps for collaboration are already defined; joint courses will be carried out next autumn with TUAS lecturer in biomedical sciences Marko Björn and his colleagues in MMU to run joint activities, and autobiographical methods will be applied for laboratory diaries and assessments, to ensure students can present concisely experimental work. Pedagogically, this will allow to widen the variety of creative assessments students have in the higher education setting, at the same time as providing digital skills during their scientific training.

\section{REFERENCES}

[1] K. Lehikoinen, Training Artists for Innovation: Guidelines for Curriculum Development. In Training Artists for Innovation. Competencies for New Contexts. Kokos Publications Series 2 (J. Heinsius \& K. Lehikoinen eds.), pp. 48-63. Helsinki: Theatre Academy of the University of the Arts Helsinki, 2013.

[2] T. Tanskanen, Kulttuurialan ylemmät ammattikorkeakoulututkinnot työelämän kehittäjinä. In Taiteen moniammatilliset kontekstit (Multiprofessional Contexts of Art). Turun ammattikorkeakoulun puheenvuoroja 94. (I. Tanskanen \& P. Juppi eds.), pp. 6-18. Turku: Turun ammattikorkeakoulu, 2017.

[3] P. Kallio, Näkyviin piirretyt. SuMu-taiteilijakirjat taidelähtöisenä kohtaamisen metorina. In Taiteen moniammatilliset kontekstit. (Multiprofessional Contexts of Art). Turun ammattikorkeakoulun puheenvuoroja 94. (I. Tanskanen \& P. Juppi eds.), pp. 36-60. Turku: Turun ammattikorkeakoulu, 2017.

[4] K. Juhola, katjajuhola. Retrieved from http://katjajuhola.fi/?cat=0

[5] A.-L. Karjalainen, Elettyä ymmärtämässä. Omaelämäkerrallinen kirjoittaminen ja teksti reflektiona sosiaalialan ammattikorkeakouluopinnoissa. (Understanding Life. Autobiographical Writing and Text as Means of Reflection in Social Studies at University of Applied Sciences). Diakonia-ammattikorkeakoulun julkaisuja: A Tutkimuksia 35. Helsinki: Diakoniaammattikorkeakoulu, 2012.

[6] P. Kosonen, Elämät sanoissa. Eletty ja kerrottu epäjatkuvuus Sarrauten, Durasin, RobbeGrillet'n ja Perecin omaelämäkerrallisissa teksteissä (Life in Words. The Lived Life and What is Told in Sarraute's, Duras', Robbe-Grillet's and Perec's Autobiographical Texts). Helsinki: Tutkijaliitto, 2000.

[7] J. Cameron, Tie luovuuteen. Henkinen polku syvempään luovuuteen (The Artists' Way). Transl. P. Pakkala. 7. p. Helsinki: Like, 2008.

[8] T. Saresma, Omaelämäkerran rajapinnoilla. Kuolema ja kirjoitus (On the Borderlines of Autobiography. The Death and Writing). Nykykulttuurin tutkimuskeskuksen julkaisuja 92. Jyväskylä: Jyväskylän yliopisto., 2007.

[9] A. Lambert, Digital Storytelling Cookbook. Retrieved from https://wrd.as.uky.edu/sites/default/files/cookbook.pdf. Berkeley, CA: Center for Digital Storytelling, 2010.

[10] I. Tanskanen, Oman elämänsä taiteilija. In Omakuva on jokaisen kuva (Self-portrait is portrait of everyone). Turun ammattikorkeakoulun oppimateriaaleja 61 (I. Tanskanen ed.), pp. 47-57. Turku: Turun ammattikorkeakoulu

[11] N. Goldberg, Hyvä kaukainen ystävä. Kuinka kirjoittaa elämäntarina (Old Friend From Far Away: The Practice of Writing Memoir). Transl. M.-R. Vainikkala. Helsinki: Kansanvalistusseura. 2009.

[12] I. Tanskanen \& P. Bartsch, Happiness as Man's Final Destination. In I as me. Making of 2000 \& 11 Self-portraits. Course Material from Turku University of Applied Sciences 81 (I. Tanskanen ed.), pp. 92-107. Turku: Turku University of Applied Sciences, 2013.

[13] I. Tanskanen, J. Antinkaapo, P. Bartsch \& L. Leka, Girls on the Art's Pathway. In I as me. Making of 2000 \& 11 Self-portraits. Course Material from Turku University of Applied Sciences 81 (I. Tanskanen ed.), pp. 140-149. Turku: Turku University of Applied Sciences, 2013. 
[14] P. Juppi \& I. Tanskanen, Digitarinatyöpajat ovat käynnistyneet Turussa. Näkymättömät Nuorten digitarinat. Retrieved from http://nakymattomat.turkuamk.fi/2016/04/12/digitarinatyopajat-kaynnistyneet-turussa/, 2016. 